\title{
Parasitic fauna in hybrid tambacu from fish farms
}

\author{
Ronilson Macedo Silva(1), Marcos Tavares-Dias ${ }^{(2)}$, Maycon Willian Reis Dias ${ }^{(2)}$, \\ Márcia Kelly Reis Dias ${ }^{(3)}$ and Renata das Graças Barbosa Marinho ${ }^{(3)}$
}

\begin{abstract}
(1)Universidade do Estado do Amapá, Avenida Presidente Vargas, no 650, CEP 68906-970 Macapá, AP, Brazil. E-mail: rony@hotmail.com.br (2)Embrapa Amapá, Rodovia Juscelino Kubitschek, Km 5, № 2.600, CEP 68903-419 Macapá, AP, Brazil. E-mail: marcos.tavares@embrapa.br, mayconw.dias@hotmail.com ${ }^{(3)}$ Universidade Federal do Amapá, Rodovia Juscelino Kubitschek, Km 2, CEP $68902-280$ Macapá, AP, Brazil. E-mail: marciakr.dias@hotmail.com, renatagbmarinho@yahoo.com.br
\end{abstract}

\begin{abstract}
The objective of this work was to evaluate the parasitic fauna of hybrid tambacu (Colossoma macropomum x Piaractus mesopotamicus) from fish farms and the host-parasite relationship. A hundred and fourteen fish were collected from four fish farms in Macapá, in the state of Amapá, Brazil, $80.7 \%$ of which were infected by: Ichthyophthirius multifiliis (Ciliophora); Piscinoodinium pillulare (Dinoflagellida); Anacanthorus spatulatus, Notozothecium janauachensis, and Mymarothecium viatorum (Monogenoidea); Neoechinorhynchus buttnerae (Acanthocephala); Cucullanus colossomi (Nematoda); Perulernaea gamitanae (Lernaeidae); and Proteocephalidae larvae (Cestoda). A total of 8,136,252 parasites were collected from the examined fish. This is the first record of N. buttnerae, C. colossomi, N. janauachensis, M. viatorum, and Proteocephalidae for hybrid tambacu in Brazil. Ichthyophthirius multifiliis was the most prevalent parasite, whereas endohelminths were the less. A positive correlation was observed between number of I. multifiliis and total length and weight of fish, as well as between number of $P$. gamitanae and total length. The infection by $I$. multifiliis had association with the parasitism by Monogenoidea. Low water quality contributes to high parasitism of hybrid tambacu by ectoparasites, which, however, does not influence the relative condition factor of fish.
\end{abstract}

Index terms: Colossoma macropomum, Ichthyophthirius multifiliis, Piaractus mesopotamicus, ectoparasite, native fish, host-parasite relationship.

\section{Parasitofauna no híbrido tambacu de pisciculturas}

Resumo - O objetivo deste trabalho foi avaliar a parasitofauna de tambacu (Colossoma macropomum $\mathrm{x}$ Piaractus mesopotamicus) de pisciculturas e a relação parasito-hospedeiro. Cento e catorze peixes foram coletados de quatro pisciculturas de Macapá, AP, $80,7 \%$ dos quais estavam infectados por: Ichthyophthirius multifiliis (Ciliophora); Piscinoodinium pillulare (Dinoflagellida); Anacanthorus spatulatus, Notozothecium janauachensis e Mymarothecium viatorum (Monogenoidea); Neoechinorhynchus buttnerae (Acanthocephala), Cucullanus colossomi (Nematoda); Perulernaea gamitanae (Lernaeidae); e larvas de Proteocephalidae (Cestoda). Um total de 8.136.252 parasitos foram coletados dos peixes examinados. Esse é o primeiro registro de $N$. buttnerae, C. colossomi, N. janauachensis, M. viatorum e Proteocephalidae para híbridos tambacu no Brasil. Ichtyophthirius multifiliis foi o parasito mais prevalente, enquanto os endohelmintos, os menos. Observou-se correlação positiva entre número de I. multifiliis e comprimento total e peso corporal dos peixes, bem como entre número de P. gamitanae e comprimento total. A infeção por I. multifiliis mostrou associação com o parasitismo por Monogenoidea. A baixa qualidade da água contribui para o alto parasitismo do hibrido tambacu por ectoparasitas, que, no entanto, não influi no fator de condição relativo dos peixes.

Termos para indexação: Colossoma macropomum, Ichthyophthirius multifiliis, Piaractus mesopotamicus, ectoparasita, peixe nativo, relação parasito-hospedeiro.

\section{Introduction}

Brazil has a large variety of native fish species with potential for cultivation, but most of them are not suited to captivity, since their eating habits, density, and appropriate management are unknown. Hybridization has been widely used in aquaculture, because interspecific fish hybrids have desirable quantitative and qualitative traits, including improved growth, harvestability, and environmental tolerance (Pinheiro et al., 1991; Lorenzen et al., 2012).

In Brazil, the tambacu hybrid, resulting from the crossbreeding of female Colossoma macropomum Cuvier, 1818 (tambaqui) and male Piaractus mesopotamicus Holmberg, 1887 (pacu), was created to assemble in one single species the qualities of these two. The tambacu is more resistant to disease than C. macropomum or P. mesopotamicus (Tavares-Dias 
et al., 2001a, 2001b, 2007; Martins et al., 2002), and grows faster than $P$. mesopotamicus (Tavares-Dias et al., 2007). General characteristics such as shape, size, diet, and grayish color are closer to the parental tambaqui. In 2010, the production of this hybrid was of 21,621.4 tons, with cultivation in several states of the North, Northeast, Southeast, and Central-West regions of Brazil (Boletim estatístico da pesca e aquicultura , 2012). Although the state of Amapá, in the North, contributed little to this production, it has great potential.

In intensive culture systems, high stocking densities have been used to increase biomass productivity. However, this can lead to the incidence of a variety of parasitoses if culture conditions are inadequate (Tavares-Dias et al., 2001a; Lizama et al., 2007; Eiras et al., 2010; Martins et al., 2010; Godoi et al., 2012), which may result in epizooties, depending on the abundance of parasites and on the disease severity. These diseases, however, are most prevalent in newly cultured species, or in newly developed culture systems, and become rare once husbandry practices are well developed.

The parasitic fauna of the hybrid tambacu has been studied mainly in the southeastern region of Brazil. Studies report the occurrence of the protozoa Piscinoodinium pillulare (Martins et al., 2000, 2002; Tavares-Dias et al., 2001a; Schalch \& Moraes, 2005), Ichthyophthirius multifiliis (Ceccarelli et al., 1990; Martins \& Romero, 1996; Tavares-Dias et al., 2001a; Martins et al., 2000, 2002), and Trichodina sp. (Ceccarelli et al., 1990; Tavares-Dias et al., 2001a; Martins et al., 2002); of Monogenoidea (Ceccarelli et al., 1990; Martins \& Romero, 1996; Tavares-Dias et al., 2001b; Martins et al., 2000, 2002); of the crustaceans Lernaea cyprinacea (Martins \& Romero, 1996; Martins et al., 2000, 2002; Tavares-Dias et al., 2001b; Schalch \& Moraes, 2005), Dolops carvalhoi (Tavares-Dias et al., 2007), Myxobolus myxosporean colossomatis (Martins et al., 1999), and Henneguya piaractus (Martins \& Romero, 1996; Martins et al., 1999); and of the digenean Posthodiplostomum sp. (Alexandrino et al., 1996). However, in the North of Brazil, including the state of Amapá, there is no knowledge of epidemiological studies on hybrid tambacu from fish farms.

Researches related to the host-parasite relationship are very useful tools to prevent diseases (Godoi et al.,
2012). Parasites have been a great concern in fish production, since they often result in reduced growth, increased susceptibility to other diseases, and fish loss. An effective disease control depends on integrated sanitary management, which considers fish species, environment, parasites, and husbandry practices. Despite the importance of field parasitological studies, with the identification of parasites and accurate diagnosis of the causes of the diseases, there is a severe scarcity of data on epidemiological and sanitary diagnostics, especially in fish farms.

The objective of this work was to evaluate the parasitic fauna of hybrid tambacu (Colossoma macropomum x Piaractus mesopotamicus) from fish farms and the host-parasite relationship.

\section{Materials and Methods}

From October 2009 to September 2010, 114 hybrid tambacu were collected in four fish farms of the municipality of Macapá, in the state of Amapá, Brazil. Each farm had different pond sizes, feeding systems (two to four times a day), and stocking densities (Table 1), and used several brands of artificial feed. However, all of them used crude protein levels of $32 \%$, during the fatten stage.

The fish were collected with a net, weighed (g), and measured in length $(\mathrm{cm})$. Then, they were necropsied for parasitological analysis. Each specimen was examined in the mouth, opercula, gills, and gastrointestinal tract. The gills were removed and analyzed with a common light microscope. The gastrointestinal tract was removed, placed in a Petri dish containing $\mathrm{NaCl}$ $(0.8 \%)$, and examined under a stereomicroscope. The methods used for collection, fixation (Eiras et al., 2006; Thatcher, 2006), and quantification of the parasites (Tavares-Dias et al., 2001a, 2001b) were performed according to previous recommendations.

Table 1. Geographical coordinates, size of the ponds, and stocking density of hybrid tambacu in four fish farms from Macapá, in the state of Amapá, Brazil.

\begin{tabular}{llcc}
\hline $\begin{array}{l}\text { Fish } \\
\text { farm }\end{array}$ & $\begin{array}{c}\text { Geographic } \\
\text { localization }\end{array}$ & $\begin{array}{c}\text { Size of } \\
\text { pond }\left(\mathrm{m}^{3}\right)\end{array}$ & $\begin{array}{c}\text { Density } \\
\left(\text { fish per } \mathrm{m}^{3}\right)\end{array}$ \\
\hline 1 & $0^{\circ} 02^{\prime} 31^{\prime \prime} \mathrm{S}, 51^{\circ} 07^{\prime} 34 " \mathrm{~W}$ & 9,000 & 1.0 \\
2 & $0^{\circ} 05^{\prime} 02^{\prime \prime} \mathrm{N}, 51^{\circ} 02^{\prime} 44^{\prime \prime} \mathrm{W}$ & 4,000 & 0.5 \\
3 & $0^{\circ} 00^{\prime} 03^{\prime \prime} \mathrm{S}, 51^{\circ} 07^{\prime} 23^{\prime \prime} \mathrm{W}$ & 1,000 & 2.0 \\
4 & $0^{\circ} 04^{\prime} 15^{\prime \prime} \mathrm{N}, 51^{\circ} 02^{\prime} 17 " \mathrm{~W}$ & 2,000 & 2.8 \\
\hline
\end{tabular}


The identification of the collected parasites was done according to Díaz-Ungria (1968), Kritsky et al. (1979), Thatcher \& Paredes (1985), Boeger et al. (2002), Belmont-Jégu et al. (2004), and Thatcher (2006). After these procedures, the parasitological indexes were determined, including prevalence, mean intensity, abundance (Bush et al., 1997), and mean relative dominance (Rohde et al., 1995).

The relative condition factor $(\mathrm{Kn})$ was investigated for parasitized and non-parasitized fish. The differences between them were compared by the t-Student test, at $5 \%$ probability. Data of total length and weight was used to determine the $\mathrm{Kn}$ of hosts (Le-Cren, 1951). The correlation coefficient of Spearman's rank (rs) was used to determine the possible correlation between total length and weight of the host with the number of parasites (Zar, 1999).

In each survey, $\mathrm{pH}$, temperature, and levels of dissolved oxygen of the ponds were measured using digital equipment, suitable for each purpose.

\section{Results and Discussion}

Temperature and $\mathrm{pH}$ were similar in all investigated fish farms (Figure 1). However, dissolved oxygen levels were low in three fish farms, with mean values not suitable for the good production performance and health maintenance of farmed fish (Martins et al., 2010; Godoi et al., 2012).

Tambacu from the four fish farms had similar parasitism levels (Table 2). The following parasites were found: Ichthyophthirius multifiliis Fouquet, 1876 (Protozoa: Ciliophora); Piscinoodinium pillulare (Schäperclaus, 1954) Lom, 1981 (Protozoa: Dinoflagellida); Anacanthorus spatulatus Kritsky, Thatcher \& Kayton, 1979; Notozothecium janauachensis Belmont-Jegu, Domingues \& Laterça, 2004; Mymarothecium viatorum Boeger, Piasecki \& Sobeck, 2002 (Monogenoidea: Dactylogyridae); Neoechinorhynchus buttnerae Golvan, 1956 (Acanthocephala: Neoechinorhynchidae); Cucullanus Colossoma Ungría-Díaz, 1968 (Nematoda: Cucullanidae); Perulernaea gamitanae Thatcher \& Paredes, 1985 (Copepoda: Lernaeidae); and Proteocephalidae Mola, 1929 (Cestoda: Eucestoda). However, no clinical signs of disease or mortality were observed in any fish during the survey.
There was a lower prevalence of I. multifiliis in the gills of tambacu from farm 1 , although the intensity and
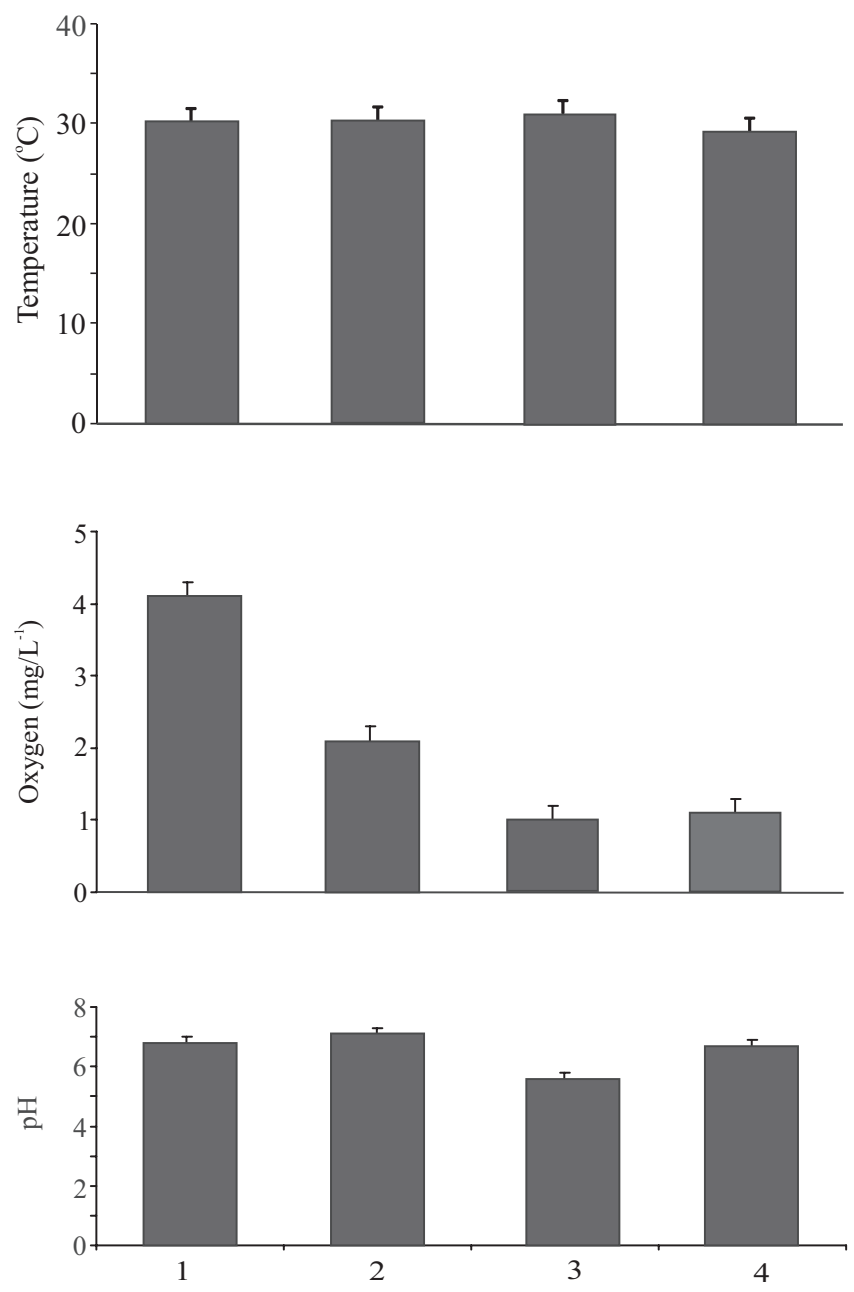

Figure 1. Mean \pm standard deviation for physicochemical parameters in the cultivation ponds of hybrid tambacu, in four fish farms from Macapá, in the state of Amapá, Brazil.

Table 2. Ranges of weight and total length, and prevalence of parasites in hybrid tambacu examined in four fish farms from Macapá, in the state of Amapá, Brazil.

\begin{tabular}{lccccc}
\hline $\begin{array}{l}\text { Fish } \\
\text { farm }\end{array}$ & $\begin{array}{c}\text { Weight } \\
(\mathrm{g})\end{array}$ & $\begin{array}{c}\text { Length } \\
(\mathrm{cm})\end{array}$ & $\mathrm{N}$ & $\begin{array}{c}\text { Parasitized } \\
\text { fish }\end{array}$ & $\begin{array}{c}\text { Prevalence } \\
(\%)\end{array}$ \\
\hline 1 & $642-2,410$ & $32.7-51.0$ & 30 & 30 & 100,0 \\
2 & $408-2,078$ & $27.0-48.0$ & 41 & 29 & 70.7 \\
3 & $174-682$ & $21.0-34.0$ & 20 & 17 & 85.0 \\
4 & $26-566$ & $12.0-34.0$ & 23 & 17 & 73.9 \\
\hline Total & - & - & 114 & 92 & 80.7 \\
\hline
\end{tabular}

Pesq. agropec. bras., Brasília, v.48, n.8, p.1049-1057, ago. 2013 DOI: 10.1590/S0100-204X2013000800034 
abundance were higher (Table 3). A high prevalence of I. multifiliis was verified in the other three fish farms, which had lower oxygen levels. These parasites are transmitted directly from fish to fish; therefore, the proximity between hosts might be very important for successful transmission. Moreover, in these three fish farms, sometimes the fish were not fed properly, due to lack of artificial ration, and the sanitary conditions were poor. Suboptimal feeding and poor water quality are stressors that result in impaired growth, which increases the susceptibility to opportunistic parasites and pathogens. However, in fish farms where fish had better nutritional and sanitary conditions, as well as adequate oxygen levels, there was a lower prevalence of this ciliate parasite (Martins et al., 2010; Omeji et al., 2010).

Despite the high prevalence, no clinical signs of ichthyophthiriasis were found, showing a chronic parasitism, since in the Amazon region there are no sudden changes in temperatures that may favor the occurrence of acute and severe infections. In contrast, in fish farms from southeastern Brazil, ichthyophthiriasis, has been the major cause of mortality in tambacu (Martins et al., 2000, 2002), especially during the winter period. Therefore, distinct patterns of infection by $I$. multifiliis can occur due to variation in environmental temperatures, depending on the region where the fish are grown.

Parasitism by $P$. pillulare occurred only in the gills of tambacu from two fish farms (Table 3). However, the observed rates of infection were lower than those described for tambacu farmed in different regions other than the Brazilian Southeast (Tavares-Dias et al., 2001a; Schalch \& Moraes, 2005), and were also lower than reports of P. mesopotamicus in the Central-West region (Sant'Ana et al., 2012), where this protozoan caused high mortality. Martins et al. (2001) reported a mortality of $61.3 \%$ in the winter season (May-August) in the Southeast region, when water temperatures ranged from 17 to $24^{\circ} \mathrm{C}$. In the Central-West region, this protozoan occurred in winter and summer, and $100 \%$ of mortality was observed by Sant'Ana et al. (2012). However, no mortality has been recorded in fish farmed in the Amazon region.

Anacanthorus spatulatus monogenoideans were found in the gills of tambacu from all four fish farms. However, $N$. janauachensis were observed parasitizing tambacu only in fish farm 4 , whereas $M$. viatorum occurred in fish farms 1 and 2. The prevalence of the infection by gill monogenoideans in fish farm 1 was lower, compared to the others fish farms, and the intensity and abundance of these parasites were lower in fish farm 3 (Table 4). The differences in infection levels between fish farms are probably due to the peculiarities of each farm, and to fish age, water quality, and management practices.

In intensive fish farming, where environmental conditions are often unfavorable for fish, monogenoideans can cause mortality (Buchmann \& Bresciani, 2006; Eiras et al., 2010), depending on the abundance and pathogenicity of the species (Buchmann \& Bresciani, 2006). This parasite provokes an excessive production of mucus on the gill filaments, decreasing the respiratory capacity of fish. The prevalence of monogenoideans in the present study was higher than the one found for tambacu cultured in the southeastern region of Brazil (Tavares-Dias et al., 2001b; Martins et al., 2002; Schalch \& Moraes, 2005), but the intensity was lower (Tavares-Dias et al., 2001b). Therefore, since these parasites are directly transmitted from fish to

Table 3. Parasitological indexes of the protozoan Ichthyophthirius multifiliis and Piscinoodinium pillulare in the gills of hybrid tambacu in four fish farms from Macapá, in the state of Amapá, Brazil.

\begin{tabular}{|c|c|c|c|c|c|c|c|c|}
\hline \multirow[t]{2}{*}{ Index } & \multicolumn{4}{|c|}{ Ichthyophthirius multifiliis } & \multicolumn{4}{|c|}{ Piscinoodinium pillulare } \\
\hline & 1 & 2 & 3 & 4 & 1 & 2 & 3 & 4 \\
\hline $\mathrm{N}$ & 30 & 41 & 20 & 23 & 30 & 41 & 20 & 23 \\
\hline Parasitized & 17 & 25 & 17 & 17 & 9 & 2 & 0 & 2 \\
\hline Prevalence (\%) & 57.7 & 61.0 & 85.0 & 73.9 & 30.0 & 4.8 & 0 & 8.7 \\
\hline Mean intensity & $201,569.8$ & $83,029.5$ & $50,595.9$ & 81,163 & $25,826.9$ & $42,174.5$ & 0 & 22,376 \\
\hline Intensity range & $29,510-282,480$ & $17,750-258,510$ & $6,264-87,000$ & $5,984-280,233$ & $14,659-37,558$ & $22,374-61,975$ & 0 & $17,976-26,775$ \\
\hline Mean abundance & $114,222.9$ & $50,627.7$ & $43,006.5$ & $59,989.7$ & 7,748 & $2,057.3$ & 0 & $1,945.7$ \\
\hline Number of parasites & $3,426,686$ & $2,075,737$ & 860,131 & $1,379,764$ & 232,442 & 84,349 & 0 & 44,751 \\
\hline
\end{tabular}


fish, the proximity among hosts in ponds might also be important for the successful transmission of this parasite.

In addition, for monogenoideans, although there is a wide variation in optimum temperature, the reproduction in some species is highly influenced by temperature (Buchmann \& Bresciani, 2006). Schalch $\&$ Moraes (2005) reported a higher prevalence of monogenoideans in tambacu in periods of higher temperatures (spring and summer), in the Southeast region of Brazil. The mean temperature of water in the present study was of $30^{\circ} \mathrm{C}$, and this high temperature, along with the low water quality, favored the reproduction of $A$. spatulatus, $M$. viatorum, and $N$. janauachensis in the gills of tambacu. Future studies on the seasonal pattern of these monogenoideans are necessary for the knowledge of their life-cycle, which is still unknown.

Parasitism by the copepod P. gamitanae occurred only in fish farm 1, with 751 specimens collected 542 in the mouth and 209 in the gills. In the mouth, the prevalence was of $100 \%(n=30)$, with a mean intensity of 18.1 parasites per host (range of 1-53). In the gill, the prevalence was of $63.3 \%(n=19)$, with a mean intensity of 11.0 parasites per host (range of 3-35). In contrast, low parasitism by $P$. gamitanae was found for farmed C. macropomum in the state of Rondônia in northern Brazil (Godoi et al., 2012).

The prevalence of this species in the mouth, gills, and nasal cavity of $C$. macropomum has been reported to be of $95 \%$, in fish farmed in Manaus, in the state of Amazonas (Benetton \& Malta, 1999). Heavy infestation of this parasite in young fish causes mortality and economic losses (Godoi et al., 2012). However, P. gamitanae has not been recorded in

Table 4. Parasitological indexes of Monogenoidea in hybrid tambacu of four fish farms from Macapá, in the state of Amapá, Brazil.

\begin{tabular}{lcccc}
\hline Index & \multicolumn{4}{c}{ Fish farm } \\
\cline { 2 - 5 } & 1 & 2 & 3 & 4 \\
\hline $\mathrm{N}$ & 30 & 41 & 20 & 23 \\
Parasitized & 17 & 30 & 17 & 17 \\
Prevalence (\%) & 56.7 & 73.2 & 85.0 & 73.9 \\
Mean intensity & 216.9 & 356 & 108.0 & 202.0 \\
Intensity range & $26-327$ & $11-868$ & $15-232$ & $38-383$ \\
Mean abundance & 122.9 & 251.8 & 91.8 & 149.3 \\
Number of parasites & 3,688 & 10,324 & 1,836 & 3,434 \\
\hline
\end{tabular}

other Brazilian regions. It seems that this parasite is currently restricted to the northern region, possibly due to a geographical barrier. Therefore, appropriate sanitary care is needed when transporting fish, in order to prevent these emerging parasites to be introduced in other fish farms.

The intensity of $P$. gamitanae increased with the growth of tambacu (Figure 2), since larger fish do not fed on plankton, as the younger ones do, which also feed on copepods in the ponds. In Catla catla, parasitized by six species of Lernaea, an increased number of parasites was associated to the body growth of fish (Tasawar et al., 2007). In the gills of Oreochromis niloticus, increased prevalence and abundance of the ectoparasite Lamproglena was found to be correlated with growth (Alves et al., 2000; Lizama et al., 2007). However, according to Alves \& Luque (2006), this relationship is more associated with the degree of specialization of the attachment organs of ectoparasites and the availability of infective forms of certain age groups of the hosts than with the availability of physical space.

In fish farm 2, 77 specimens of $N$. buttnerae were collected from the intestine of five tambacu, with a prevalence of $12.5 \%$ and mean intensity of 18.5 parasites per host (range of 1-56). There are no records of these helminths parasitizing tambacu in other locations in Brazil. However, a prevalence of $100 \%$ and a mean intensity of 81.3 specimens per host were responsible for the mortality of $C$. macropomum farmed in Manaus, in the state of Amazonas (Malta

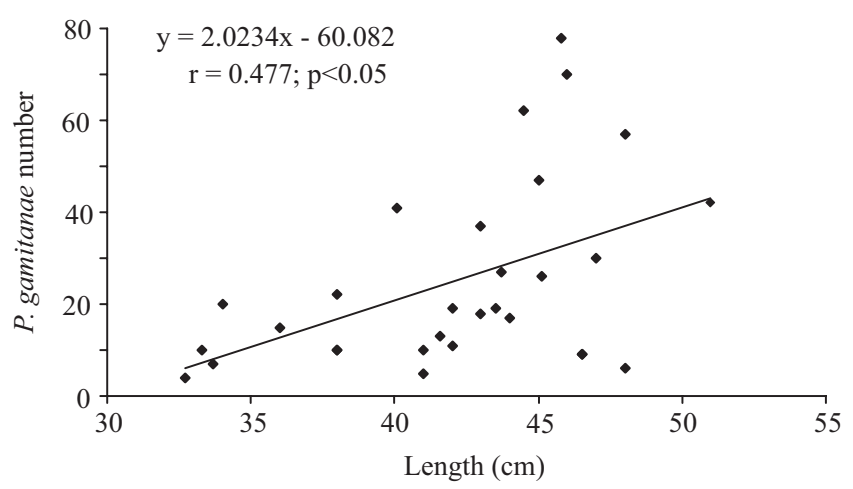

Figure 2. Correlation between the length and intensity of Perulernaea gamitanae in the gills and mouth of hybrid tambacu $(n=30)$ of fish farms from Macapá, in the state of Amapá, Brazil.

Pesq. agropec. bras., Brasília, v.48, n.8, p.1049-1057, ago. 2013 DOI: $10.1590 / \mathrm{S} 0100-204 X 2013000800034$ 
et al., 2001). Acanthocephalan infection causing epizooty in farmed fish has been rarely reported (Eiras et al., 2006, 2010), since the occurrence of Neoechinorhynchus species is more common in natural populations. Neoechinorhynchus species have a life cycle that involves ostracods as intermediate hosts and fish as definitive hosts (Martínez-Aquino et al., 2009). The pathogenesis depends on the species of acanthocephalan, infection intensity, size of the parasites and hosts, and proboscis penetration level (Eiras et al., 2006). Treatment for this gastrointestinal parasite is difficult and, in high abundance, the fish do not fed. Malta et al. (2001) recommend the sacrifice of the severely infected fish, in order to eliminate adult parasites. Furthermore, these authors suggest disinfection with calcium oxide and the drying of tanks, promoting the elimination of the eggs and larvae of these parasites, which develop in intermediate hosts.

One adult specimen of the nematode C. colossomi was collected in the intestine of one specimen of tambacu (prevalence of $4.3 \%$ ) in fish farm 4 . Nematoda are the most common endohelminths in natural populations, in different environments. These parasites can decrease the growth and sexual maturation of farmed fish, but this disease rarely causes epizooty (Eiras et al., 2010). Cucullanidae nematodes are viviparous, and a micro-crustacean - usually a copepod - is needed as an intermediate host (Thatcher, 2006). Since only one tambacu was parasitized by $C$. colossomi, it was probably infected by the accidental ingestion of the shrimp Macrobrachium amazonicum, which is an intermediate host of this nematode, present in the studied fish farms. Ahmed et al. (2007) reported 100\% of infection by Procamallanus heteropneustes on farmed Heteropneustes fossilis, with mean intensity of 14.4 parasites per host. These authors concluded that the ingestion of copepods was the cause of this endoparasitism, since these crustaceans were frequently infected with larvae of $P$. heteroneustus.

One hybrid tambacu had three specimens of adult Cestoda, from the Proteocephalidae family. Martins et al. (2000) also observed low levels of infection by proteocephalid cestodes in farmed Cyprinus carpio, in southeastern Brazil. In teleost fish, approximately $90 \%$ of the cestode parasites are from the Proteocephalus species (Rego, 2004). However, infections by cestodes species are uncommon in farmed fish, due to their complex life cycle, which requires more than one intermediate host.

Among the 114 examined tambacu, the monogenoideans $A$. spatulatus, $M$. viatorum, and $N$. janauachensis accounted for $77.2 \%$ of the infections, followed by $I$. multifiliis $(67.5 \%)$. The greatest abundance was found for the protozoan I. multifiliis, and the lowest, for the nematode C. colossomi (Table 5). However, the condition factor of parasitized tambacu $(\mathrm{Kn}=1.000 \pm 0.030)$ did not differ from that of non-parasitized ones $(1.000 \pm 0.028)$ and showed no significant difference $(\mathrm{p}=0.028)$.

There was a frequent association of I. multifiliis and Monogenoidea in tambacu gill (Figure 3). This parasitic association was relatively smaller in fish from fish farm 1, which showed the lowest prevalence for both parasites. A high positive correlation $(\mathrm{p}<0.001)$ was observed between the intensity of I. multifiliis in the gills and the weight and length of tambacu (Figure 4). Gills are sites of filter feeding; therefore, bigger fish cover wider areas in search of food and, as result, take in more food than smaller ones, with higher exposure to parasites (Omeji et al., 2010). Similar findings were confirmed for Heterobranchus longifilis from natural and cultured environments (Omeji et al., 2010).

Table 5. Parasitological indexes of hybrid tambacu $(n=114)$ of four fish farms from Macapá, in the state of Amapá, Brazil.

\begin{tabular}{|c|c|c|c|c|c|}
\hline Parasite & Prevalence $(\%)$ & Mean intensity \pm SD & Mean abundance & Relative dominance & Infection site \\
\hline Ichthyophthirius multifiliis & 67.5 & $100,944.3 \pm 82,601.9$ & $67,296.2$ & 0.94300 & Gills \\
\hline Piscinoodinium pillulare & 11.4 & $26,764 \pm 8,390$ & $3,052.0$ & 0.04277 & Gills \\
\hline Monogenoidea & 77.2 & $348 \pm 370.5$ & 268.6 & 0.00376 & Gills \\
\hline Perulernaea gamitanae & 26.3 & $25.0 \pm 20.4$ & 6.6 & 0.00009 & Gills and mouth \\
\hline Neoechinorhynchus buttnerae & 4.4 & $15.4 \pm 23.4$ & 0.7 & 0.000009 & Intestine \\
\hline Cucullanus colossomi & 0.9 & $1.0 \pm 0$ & 0.01 & - & Intestine \\
\hline Proteocephalidae & 0.9 & $1.0 \pm 0$ & 0.01 & - & Intestine \\
\hline
\end{tabular}




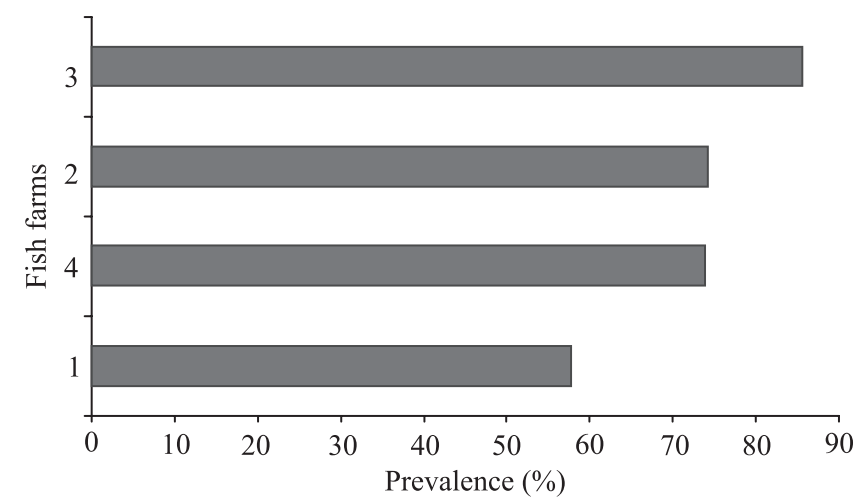

Figure 3. Prevalence of the association between infection by monogenoideans and Ichthyophthirius multifilis in the gills of hybrid tambacu $(n=76)$ in four fish farms from Macapá, in the state of Amapá, Brazil.
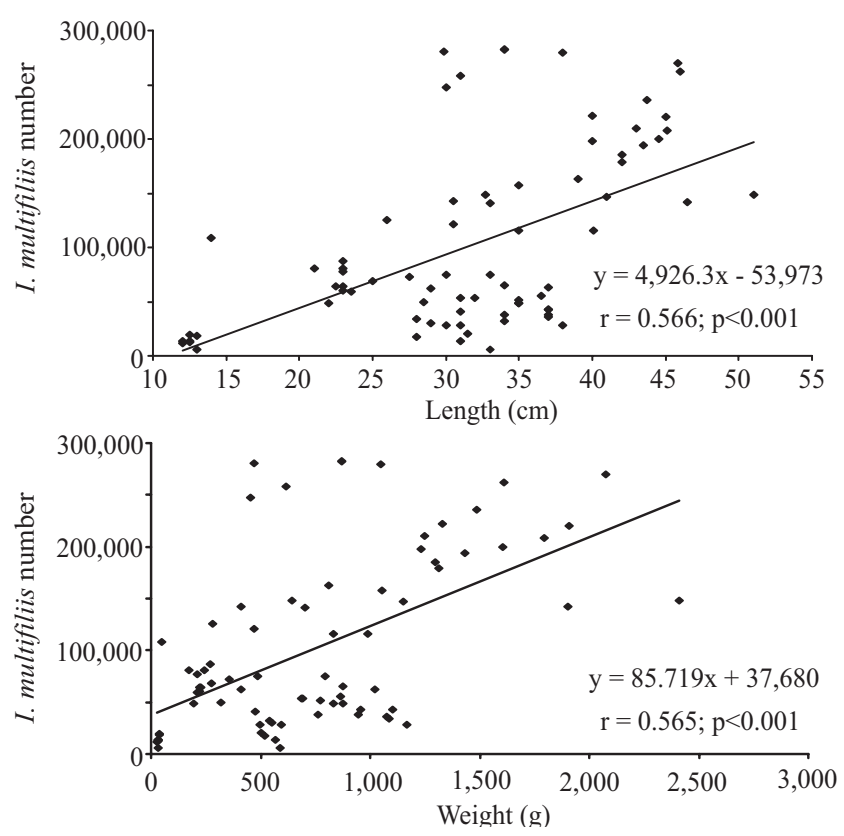

Figure 4. Relationship between the intensity of Ichthyophthirius multifiliis and biometric parameters of hybrid tambacu $(n=76)$ in four fish farms from Macapá, in the state of Amapá, Brazil.

\section{Conclusions}

1. The parasitic fauna of hybrid tambacu from Macapá, in the state of Amapá, Brazil, is not diverse, with two protozoans, three monogenoideans, one lernaeid, and three endohelminth species in the evaluated fish farms.
2. Low water quality contributes to high parasitism by ectoparasites in fish farms, but this high parasitism has no influence on the relative condition factor $(\mathrm{Kn})$ of hybrid tambacu.

3. This is the first record of Neoechinorhynchus buttnerae, Cucullanus colossomi, Anacanthorus spatulatus, Mymarothecium viatorum, Notozothecium janauachensis, and Proteocephalidae for hybrid tambacu in Brazil.

\section{Acknowledgements}

To Conselho Nacional de Desenvolvimento Científico e Tecnológico ( $\mathrm{CNPq})$, for the financial support and for the grant to Marcos Tavares-Dias.

\section{References}

AHMED, M.S.; IQBAL, T.; MAHMOOD, A.; GULZARIN, M.; ABID, M. Helminth parasites of some freshwater fishes. Punjab University Journal Zoology, v.22, p.1-6, 2007.

ALEXANDRINO, A.C.; MANDELLI JUNIOR, J.; RANZANI-PAIVA, M.J.T.; EIRAS, A.C. das; AYROSA, L.M. da S.; CABRAL, I.P.; SILVEIRA, V.R. da. Metacercariose em plantel de tambacu, híbrido de fêmea de tambaqui (Colossoma macropomum, Teleostei, Characidae) com macho de pacu (Piaractus mesopotamicus, Teleostei, Characidae). (Relato de caso). Revista Ceres, v.43, p.591-596, 1996.

ALVES, D.R.; LUQUE, J.L. Ecologia das comunidades de metazoários parasitos de cinco espécies de escombrídeos (Perciformes: Scombridae) do litoral do Estado do Rio de Janeiro, Brasil. Revista Brasileira de Parasitologia Veterinária, v.15, p.167-181, 2006.

ALVES, D.R.; LUQUE, J.L.; PARAGUASSU, A.L. Ectoparasitas da tilápia nilótica Oreochromis niloticus (Osteichthyes: Cichlidae) da estação de piscicultura da UFRJ. Revista da Universidade Rural Ciências e Vida, v.22, p.81-85, 2000.

BELMONT-JÉGU, E.; DOMINGUES, M.V.; MARTINS, M.L. Notozothecium januachensis n. sp. (Monogenoidea: Dactylogyridae) from wild and cultured tambaqui, Colossoma macropomum (Teleostei: Characidae: Serrasalminae) in Brazil. Zootaxa, v.736, p.1-8, 2004.

BENETTON, M.L.F. de N.; MALTA, J.C. de O. Morfologia dos estágios de náuplios e copepodito I de Perulernaea gamitanae Thatcher \& Paredes, 1985 (Crustacea: Cyclopoida: Lernaeide), parasita do tambaqui Colossoma macropomum (Cuvier, 1818), (Osteichthyes: Characidae), cultivados em laboratório. Acta Amazonica, v.29, p.97-121, 1999.

BOEGER, W.A.; PIASECKI, W.; SOBECKA, E. Neotropical Monogenoidea. 44. Mymarothecium viatorum $\mathrm{sp}$. $\mathrm{n}$. (Ancyrocephalinae) from the gills of Piaractus brachypomus (Serrasalmidae, Teleostei) captured in a warm-water canal of 
a power plant in Szczecin, Poland. Acta Ichthyologica et Piscatoria, v.32, p.157-162, 2002.

BOLETIM estatístico da pesca e aquicultura - Brasil 2010. Brasília: Ministério da Pesca e Aquicultura, 2012. 128p.

BUCHMANN, K.; BRESCIANI, J. Monogenea (Phylum Platyhelminthes). In: WOO, P.T.K. (Ed.). Fish diseases and disorders. Volume 1. Protozoan and metazoan infections. $2^{\text {nd }}$ ed. Cambridge: CABI, 2006. p.297-344.

BUSH, A.O.; LAFFERTY, K.D.; LOTZ, J.M.; SHOSTAK, W. Parasitology meets ecology on its own terms: Margolis et al. revisited. Journal of Parasitology, v.83, p.575-583, 1997. DOI: $10.2307 / 3284227$.

CECCARELLI, P.S.; FIGUEIRA, L.B.; FERRAZ-LIMA, C.L.B.; OLIVEIRA, C.A. Observações sobre a ocorrência de parasitos no CEPTA entre 1983 e 1990. Boletim Técnico do Cepta, v.3, p.43-55, 1990.

DÍAZ-UNGRIA, C. Helmintos de peces de Venezuela con descripción de un género y tres especies nuevas. Boletín de la Sociedad Venezolana de Ciencias Naturales, v.27, p.537-570, 1968.

EIRAS, J.C.; TAKEMOTO, R.M.; PAVANELLI, G.C. Diversidade dos parasitas de peixes de água doce do Brasil. Maringá: Clichetec, 2010.333p.

EIRAS, J.C.; TAKEMOTO, R.M.; PAVANELLI, G.C. Métodos de estudo e técnicas laboratoriais em parasitologia de peixes. Maringá: EDUEM, 2006. 199p.

GODOI, M.M.I. de M.; ENGRACIA, V.; LIZAMA, M. de Los A.; TAKEMOTO, R.M. Parasite-host relationship between the tambaqui (Colossoma macropomum Cuvier 1818) and ectoparasites, collected from fish farms in the city of Rolim de Moura, State of Rondônia, Western Amazon, Brazil. Acta Amazonica, v.42, p.515-524, 2012. DOI: 10.1590/S0044-59672012000400009.

KRITSKY, D.C.; THATCHER, V.E.; KAYTON, R.J. Neotropical Monogenoidea. 2. The Anacanthorinae Price, 1967, with the proposal of four new species of Anacanthorus Mizelle \& Price, 1965, from Amazonian fishes. Acta Amazonica, v.9, p.355-361, 1979.

LE CREN, E.D. The length-weight relationship and seasonal cycle in gonad weight and condition in the perch (Perca fluviatilis). Journal of Animal Ecology, v.20, p.201-219, 1951. DOI: $10.2307 / 1540$.

LIZAMA, M. de Los A.P.; TAKEMOTO, R.M.; RANZANI-PAIVA, M.J.T.; AYROZA, L.M. da S.; PAVANELLI, G.C. Relação parasito-hospedeiro em peixes de pisciculturas da região de Assis, Estado de São Paulo, Brasil. 2. Piaractus mesopotamicus (Holmberg, 1887). Acta Scientiarum. Biological Sciences, v.29, p.437-445, 2007. DOI: 10.4025/actascibiolsci.v29i4.888.

LORENZEN, K.; BEVERIDGE, M.C.M.; MANGEL, M. Cultured fish: integrative biology and management of domestication and interactions with wild fish. Biological Reviews, v.87, p.639-660, 2012. DOI: 10.1111/j.1469-185X.2011.00215.x.

MALTA, J.C.O.; GOMES, A.L.S.; ANDRADE, A.M.S.; VARELLA, A.M.B. Infestações maciças por acantocéfalos, Neoechinorhynchus buttnerae Golvan, 1956, (Eoacanthocephala: Neoechinorhychidae) em tambaquis jovens, Colossoma macropomum (Cuvier, 1818), cultivados na Amazônia Central. Acta Amazonica, v.31, p.133-143, 2001.

MARTÍNEZ-AQUINO, A.; REYNA-FABIÁN, M.E.; ROSAS-VALDEZ, R.; RAZO-MENDIVIL, U.; PÉREZ-PONCE DE LEÓN, G.; GARCÍAVARELA, M. Detecting a complex of cryptic species within Neoechinorhynchus golvani (Acanthocephala: Neoechinorhynchidae) inferred from ITSs and LSU rDNA gene sequences. The Journal of Parasitology, v.95, p.1040-1047, 2009. DOI: 10.1645/GE-1926.1.

MARTINS, M.L.; AZEVEDO, T.M.P.; GHIRALDELLI, L.; BERNADI, N. Can the parasitic fauna on Nile tilapias be affected by different production systems? Anais da Academia Brasileira de Ciências, v.82, p.493-500, 2010. DOI: 10.1590/ S0001-37652010000200024.

MARTINS, M.L.; MORAES, F.R.; FUJIMOTO, R.Y.; ONAKA, E.M.; NOMURA, D.T.; SILVA, C.A.H.; SCHALCH, S.H.C. Parasitic infections in cultivated freshwater fishes: a survey of diagnosticated cases from 1993 to 1998. Revista Brasileira de Parasitologia Veterinária, v.9, p.23-28, 2000.

MARTINS, M.L.; MORAES, J.R.E.; ANDRADE, P.M.; SCHALCH, S.H.C.; MORAES, F.R. Piscinoodinium pillulare (Schäperclaus 1954) Lom, 1981 (Dinoflagellida) infection in cultivated freshwater fish from Northeast region of São Paulo State, Brazil. Parasitological and pathological aspects. Revista Brasileira de Biologia, v.61, p.639-644, 2001. DOI: 10.1590/ S1519-69842001000400013.

MARTINS, M.L.; ONAKA, E.M.; MORAES, F.R. de; BOZZO, F.R.; PAIVA, A. de M. e F.C.; GONÇALVES, A. Recent studies on parasitic infections of freshwater cultivated fish in the state of São Paulo, Brazil. Acta Scientiarum. Biological Sciences, v.24, p.981-985, 2002.

MARTINS, M.L.; ROMERO, N.G. Efectos del parasitismo sobre el tejido branquial en peces cultivados: estudio parasitologico e histopatologico. Revista Brasileira de Zoologia, v.13, p.489-500, 1996. DOI: 10.1590/S0101-81751996000200017.

MARTINS, M.L.; SOUZA, V.N. de; MORAES, J.R.E. de; MORAES, F.R. de; COSTA, A.J. da. Comparative evaluation of the susceptibility of cultivated fishes to the natural infection with myxosporean parasites and tissue changes in the host. Revista Brasileira de Biologia, v.59, p.263-269, 1999. DOI: 10.1590/ S0034-71081999000200010.

OMEJI, S.; SOLOMON, S.G.; OBANDE, R.A. A comparative study of the common protozoan parasites of Heterobranchus longifilis from the wild and cultured environments in Benue State. Pakistan Journal of Nutrition, v.9, p.865-872, 2010. DOI: 10.3923/pjn.2010.865.872.

PINHEIRO, M.H.P.; SILVA, J.W.; NOBRE, M.I.S.; PINHEIRO, F.A. Cultivo do híbrido tambaqui, Colossoma macropomum Cuvier, 1818, com a pirapitinga, C. brachypomum Cuvier, 1818, na densidade de 5.000 peixes/ha. Revista Ciência Agronômica, v.22, p.77-87, 1991.

REGO, A.A. Current state of knowledge of cestodes from Neotropical freshwater fishes and rays. Revista Brasileira de Zoociências, v.6, p.61-79, 2004. 
ROHDE, K.; HAYWARD, C.; HEAP, M. Aspects of the ecology of metazoan ectoparasites of marine fishes. International Journal for Parasitology, v.25, p.945-970, 1995. DOI: 10.1016/0020-7519(95)00015-T.

SANT'ANA, F.J.F. de; OLIVEIRA, S.L. de; RABELO, R.E.; VULCANI, V.A.S.; SILVA, S.M.G. da; FERREIRA-JÚNIOR, J.A. Surtos de infecção por Piscinoodinium pillulare e Henneguya spp. em pacus (Piaractus mesopotamicus) criados intensivamente no Sudoeste de Goiás. Pesquisa Veterinária Brasileira, v.32, p.121-125, 2012. DOI: 10.1590/S0100-736X2012000200005.

SCHALCH, S.H.C.; MORAES, F.R. de. Distribuição sazonal de parasitos branquiais em diferentes espécies de peixes em pesque-pague do município de Guariba-SP, Brasil. Revista Brasileira de Parasitologia Veterinária, v.14, p.141-146, 2005.

TAVARES-DIAS, M.; MARTINS, M.L.; MORAES, F.R. Fauna parasitária de peixes oriundos de "pesque-pague" do município de Franca, São Paulo, Brasil. I. Protozoários. Revista Brasileira de Zoologia, v.18, p.67-79, 2001a. DOI: 10.1590/ S0101-81752001000500005.
TAVARES-DIAS, M.; MORAES, F.R.; MARTINS, M.L.; KRONKA, S.N. Fauna parasitária de peixes oriundos de "pesque-pagues" do município de Franca, São Paulo, Brasil. II. Metazoários. Revista Brasileira de Zoologia, v.18, p.81-95, 2001b. DOI: 10.1590/S0101-81752001000500006.

TAVARES-DIAS, M.; MORAES, F.R.; ONAKA, E.M.; REZENDE, P.C.B. Changes in blood parameters of hybrid tambacu fish parasitized by Dolops carvalhoi (Crustacea, Branchiura), a fish louse. Veterinarski Arhiv, v.77, p.355-364, 2007.

TASAWAR, Z.; UMER, K.; HAYAT, C.S. Observations on lernaeid parasites of Catla catla from a fish hatchery in Muzaffargarh, Pakistan. Pakistan Veterinary Journal, v.27, p.17-19, 2007.

THATCHER, V.E. Amazon fish parasites. $2^{\text {nd }}$ ed. Sofia: Pensoft, 2006. 508p.

THATCHER, V.E.; PAREDES, V. A parasitic copepod, Perulernaea gamitanae gen. et sp. nov. (Cyclopoida: Lernaeidae), from the nasal fossae of a Peruvian Amazon food fish. Amazoniana, v.9, p.169-175, 1985.

ZAR, J.H. Biostatistical analysis. $4^{\text {th }}$ ed. Englewood Cliffs: Prentice-Hall, 1999. 663p.

Received on May 25, 2011 and accepted on February 26, 2013 